\title{
Kesulitan Menyimak dan Strategi Mahasiswa dalam Memahami Bagian Listening Comprehension pada Tes TOEIC
}

\author{
Lina Meilinda, Siti Yuliah \\ Jurusan Bahasa Inggris, Politeknik Negeri Bandung \\ Bandung, Indonesia \\ E-mail: lina.meilinda@polban.ac.id, siti.yuliah@polban.ac.id
}

\begin{abstract}
This study is aimed to identify the difficulties to comprehend listening activities experienced by students and their strategies in understanding Listening Comprehension section of TOEIC test. Descriptive qualitative method was employed to find out and analyze the difficulties and strategies the students implemented. The research was carried out at English Department of Politeknik Negeri Bandung with the population of the third semester students in Academic Year 2017/2018. There were 22 students as the subject in this study. Data were collected by questionnaires and interview to confirm students' answers. The results showed that the major problems encountered by students were unfamiliar vocabulary, accents of the speaker, speed of speech, lack of concentration, and quality of recorded materials. Listening strategies implemented by students were mostly metacognitive strategy since in this strategy they obtain the awareness of the materials they are listening to in a more cautious way. This method is about the ways of planning, monitoring and assessing the collected information from the listening section the same as pre listening activities. Students applying metacognitive strategies have the benefits such as they can use appropriate learning strategy to master learning materials; they comprehend learning materials more quickly and integrate the knowledge seriously; they put themselves to be loyal receivers and can be properly adaptable to all conditions; they have high confidences in themselves to get help when needed from their peers, teachers, or family; they pay attention to the materials and assess themselves as to how to be successful learners; and they properly deal with the problems in doing their task.
\end{abstract}

Keywords: Students’ Difficulties, Listening Comprehension, Listening Strategies

\section{PENDAHULUAN}

Menyimak merupakan satu dari empat keterampilan bahasa ( menyimak, berbicara, membaca dan, menulis) yang harus dikuasai oleh pembelajar. Dalam kegiatan seharihari, menyimak memainkan peranan yang sangat penting, seperti ketika belajar, berkomunikasi, bertukar informasi, dan sebagainya. Tanpa menyimak dengan baik, kita tidak dapat melakukan komunikasi dengan baik pula.

Ketika pembelajar menyimak dalam bahasa Inggris, mereka menghadapi kesulitan dalam memahami apa yang diucapkan oleh penutur asli. Menurut Gilakjani dan Sabouri 
(2016) setidaknya ada beberapa kesulitan dalam menyimak, seperti aksen penutur, kosa kata yang tidak dikenal, dan kecepatan berbicara penutur.

Kesulitan dalam menyimak dihadapi juga oleh mahasiswa ketika mereka mengikuti TOEIC (Test of English for International Communication), yaitu pada bagian Listening Comprehension. Bagian ini terdiri atas Photographs, Question-Response, Conversations, dan Talks. Pada bagian Photographs diperlukan kemampuan dalam menganalisis gambar dan pilihan jawaban. Untuk bagian Question-Response, Conversations, dan Talks perlu pengembangan kemampuan dalam menganalisis pilihan jawaban, jenis-jenis pertanyaan, dan fungsi bahasa (language functions). Bagian Talks merupakan ceramah singkat dari penutur tunggal. Topiknya dapat meliputi cuaca, pengumuman, dan iklan. Sangatlah penting bagi para pembelajar untuk memahami keempat bagian dari Listening Comprehension section. Penelitian ini akan mencari akar permasalahan yang dihadapi oleh pembelajar ketika memahami bagian Listening Comprehension dalam tes TOEIC dan bagaimana strategi pembelajar dalam mengatasi kesulitan tersebut.

Dari uraian yang telah dikemukakan di atas, maka dilakukan adanya suatu penelitian yang 1) mengidentifikasi kesulitan-kesulitan yang dihadapi mahasiswa ketika memahami bagian Listening Comprehension dalam tes TOEIC, dan 2) mengidentifikasi strategi yang dilakukan mahasiswa dalam mengatasi kesulitan-kesulitan tersebut. Hasil dari penelitian ini diharapkan memberikan nilai yang berfaedah untuk mengembangkan pengajaran mata kuliah Listening bagi dosen pengampu dan kemampuan menyimak bagi mahasiswa yang belajar bahasa Inggris khususnya ketika mereka mengikuti tes TOEIC.

\section{TINJAUAN PUSTAKA}

\section{Menyimak}

Tarigan (1991:4) mendefinisikan menyimak sebagai suatu kegiatan yang meliputi aktivitas mendengarkan dengan sungguh-sungguh bunyi yang berhubungan dengan bahasa (linguistik), mengidentifikasi, menilik, menilai dan mereaksi atas makna yang terkandung didalamnya. 
“Aktivitas menyimak adalah suatu proses kegiatan mendengarkan lambang lisanlisan dengan penuh perhatian, pemahaman, apresiasi, serta interpretasi untuk memperoleh informasi, menangkap isi, serta memahami makna komunikasi yang disampaikan oleh si pembicara melalui ujaran atau bahasa lisan” (Tarigan, 1985:19)

Kegiatan menyimak mencakup beberapa aktifitas. Aktifitas tersebut yaitu penglihatan, pendengaran, penghayaani, ingatan, pemahaman dan suasana yang mengikuti bunyi bahasa yang disimak dengan disertai usaha agar dapat menangkap makna yang dikandungnya. Dengan kata lain, kegiatan menyimak mengandung unsur kesengajaan, perhatian dan pengertian. Ketiga unsur tersebut merupakan hal yang utama dalam aktifitas menyimak.

Dari beberapa pendapat yang sudah dibahas di bagian sebelumnya, kesimpulan yang dapat dibuat adalah bahwa aktifitas menyimak merupakan suatu aktifitas mendengarkan dengan penuh konsentrasi, untuk memahami, mengapresiasi serta menginterpretasi sebuah informasi. Selain itu juga, menyimak adalah sebuah aktifitas untuk memahami content atau message dari komunikasi lisan yang telah dilakukan oleh penutur.

\section{Manfaat dan Tujuan Menyimak}

Keterampilan menyimak dapat memberikan manfaat antara lain: Pertama, menyimak bisa memperkaya pemahaman dan menambah pengalaman yang bernilai bagi kehidupan karena menyimak mempunyai aspek-aspek informasi tertentu yang dapat menambah pengalaman. Kedua, menyimak dapat meningkatkan kemampuan akademik dan pendalaman ilmu pengetahuan. Ketiga, menyimak dapat meningkatkan vocabulary serta perbendaharaan ungkapan yang tepat, bermutu; semakin banyak menyimak semakin lancar berkomunikasi dan kata-kata yang digunakan lebih kaya dan bervariasi. Keempat, menyimak dapat membuka cakrawala pikiran, menghayati kehidupan lebih bijaksana, serta membangun keterbukaan dan sikap obyektif. Kelima, menyimak dapat menjadikan diri semakin peduli terhadap masalah sosial. Keenam, melalui aktifitas menyimak, kemampuan diri dalam melihat adanya nilai keindahan, dapat lebih ditingkatkan apabila bahan yang disimak memang mengandung nilai bahasa ang indah. Aktifitas menyimak yang sering dilakukan, dapat mengembangkan perilaku yang mencerminkan penghargaan terhadap karya atau pendapat lain. Yang ketujuh, menyimak dapat mengembangkan fikiran yang kreatif untuk memproduksi teks yang 
mencerminkan jati diri sang penulis atau pembicara. Dengan banyak menyimak, akan diperoleh gagasan-gagasan yang asli dan dipetik pengalaman yang bermanfaat. Hal ini dapat memberi dorongan untuk giat berkarya dan kreatif (Setiawan, dalam Darmawan, 2001: 11-12).

\section{Kesulitan Dalam Menyimak}

Menurut Bingol, Celik, Yidliz, dan Tugrul (2014) ada beberapa kesulitan yang dihadapi mahasiswa dalam proses menyimak. Beberapa di antaranya adalah:

1. Kualitas materi yang direkam dan hasil rekaman.

Di beberapa laboratorium bahasa dan kelas, pengajar menggunakan materi-materi yang direkam dengan hasil rekaman yang berkualitas rendah. Kualitas sound system yang rendah juga dapat mempengaruhi pemahaman dalam menyimak.

2. Perbedaan budaya

Mahasiswa seharusnya memahami pengetahuan budaya dari bahasa yang sedang dipelajarinya.

3. Aksen penutur

Menurut Goh (1999), 66\% pembelajar menyatakan aksen penutur sebagai salah satu faktor penting dalam memahami menyimak. Aksen yang tidak dikenal akan menyulitkan pembelajar untuk memahami apa yang diucapkan.

4. Kosakata yang tidak dikenal

Ketika materi menyimak terdiri atas kata-kata yang dikenal akan memudahkan pembelajar untuk memahaminya.

5. Panjang dan kecepatan menyimak

Menurut Underwood (1989) kendala-kendala yang mempengaruhi proses memahami menyimak adalah sebagai berikut:

a. Pembelajar tidak dapat mengatur kecepatan ujaran

b. Pembelajar tidak bisa meminta kata-kata diulangi kembali atau tidak bisa meminta untuk diputar kembali rekaman tersebut

c. Pembelajar tidak memiliki pengetahuan kosakata yang banyak

d. Pembelajar kurang memiliki pengetahuan konteks

e. Pembelajar tidak mudah berkonsentrasi pada materi menyimak 


\section{Strategi Memahami Dalam Menyimak}

Menurut Bingol (2014) ada tiga tipe strategi untuk memahami dalam menyimak, yaitu:

\section{Strategi Kognitif}

Strategi yang berhubungan dengan pemahaman dan pengumpulan masukan pada ingatan jangka pendek dan ingatan jangka panjang untuk dipanggil ketika akan dimanfaatkan kembali. Strategi kognitif adalah metode penyelesaian masalah yang berhubungan dengan kegiatan pembelajaran dan fasilitas belajar.

\section{Strategi Metakognitif}

Strategi metakognitif adalah teknik menajemen yang diterapkan oleh pembelajar untuk memantau cara belajar mereka melalui perencanaan, pengecekan, penilaian, dan perubahan. Holden (2004 dalam Bingol, dkk., 2014) menyatakan juga bahwa pada strategi ini pembelajar sadar ketika menyimak materi. Pada strategi ini pula para pembelajar belajar bagaimana merencanakan, memonitor dan mengevaluasi informasi yang dikumpulkan dari bagian menyimak. Menurut Wenden (1998 dalam Bingol, dkk., 2014), pembelajar yang menggunakan strategi metakognitif memiliki kelebihan sebagai berikut:

a. Pembelajar dapat menggunakan strategi yang tepat untuk menguasai materi.

b. Pembelajar dapat memahami materi dengan lebih cepat dan memadukan ilmu pengetahuan secara mendalam.

c. Pembelajar dapat memposisikan dirinya sebagai pembelajar yang menerima secara penuh materi yang diajarkan dan dapat menyesuaikan diri dengan semua situasi.

d. Pembelajar memiliki kepercayaan diri untuk menerima masukan dari teman, guru, atau keluarga saat diperlukan.

e. Pembelajar dapat menyelidiki dan mengevaluasi cara untuk menjadi pembelajar yang sukses.

f. Pembelajar dapat mengatasi situasi yang bermasalah melalui latihan yang mereka kerjakan. 


\section{Strategi Sosioafektif}

Vandergrift (2003) dan Abdalhamid (2012) menyatakan bahwa strategi ini adalah teknik yang digunakan pembelajar untuk bekerja sama dengan yang lainnya, mengecek pemahaman mereka, dan mengurangi kekhawatiran mereka dalam memahami materi. Hal ini sesuai dengan hasil riset dari Aneiro (1989) bahwa ada hubungan yang erat antara kecemasan yang rendah dan penampilan menyimak yang tinggi: yaitu penggunaan strategi afektif memudahkan untuk meningkatkan pemahaman menyimak.

\section{METODOLOGI}

Di dalam penelitian ini, dipakai metode deskriptif yang termasuk ke dalam jenis metode dari penelitian kualitatif. Metode ini sering disebut sebagai metode deskriptif kualitatif. Dalam penelitian ini digunakan data berupa uraian tertulis atau lisan yang bersumber dari partisipan. Metode ini digunakan karena pengkajian terhadap kesulitan dan strategi menghasilkan data deskriptif atau dengan kata lain pengumpulan data deskriptif dari penelitian ini dituangkan dalam bentuk laporan dan uraian.

Subyek penelitian ini adalah mahasiswa Program Studi D3 Bahasa Inggris Semester III Tahun Akademik 2018/2019 Politeknik Negeri Bandung. Jumlah subyek yang diteliti adalah 22 mahasiswa.

\section{Teknik Pengumpulan Data}

Teknik yang digunakan dalam penelitian ini adalah dengan cara penyebaran angket dan wawancara. Angket yang digunakan dalam penelitian ini terdiri atas 2 jenis, yaitu angket untuk mengidentifikasi jenis kesulitan menyimak pada bagian Listening Comprehension dalam tes TOEIC dan angket untuk mengetahui strategi menyimak yang dilakukan mahasiswa. Wawancara dilakukan pada 10 dari 22 subyek penelitian untuk mengkonfirmasi dan mengklarifikasi jawaban dari angket yang telah dijawab mereka.

\section{Teknik Analisis Data}

Data dari hasil angket dianalisis melalui langkah-langkah berikut: 


\section{Identifikasi}

Mengidentifikasi jawaban angket untuk memilah jawaban yang berisi kesulitankesulitan yang dihadapi mahasiswaatau strategi yang digunakan oleh mahasiswa dalam mengatasi kesulitan-kesulitannya.

2. Merekam data ke dalam tabulasi

Data yang telah diperoleh dan diidentifikasi ditampilkan ke dalam tabel agar memudahkan dalam memahaminya.

\section{Interpretasi}

Hasil rekam data dinterpretasikan menggunakan teori yang sesuai dengan kajian.

Khusus untuk wawancara, pertanyaan-pertanyaan telah disiapkan terlebih dahulu, hal ini dilakukan agar memudahkan proses wawancara. Informasi-informasi penting dari wawancara dicatat. Setelah data dikumpulkan dan dipilah, lalu dilakukan transkripsi hasil wawancara.

\section{HASIL DAN PEMBAHASAN}

\section{Analisis data dari angket tentang jenis-jenis kesulitan menyimak dan penyebabnya}

Hasil analisis data dari angket tersebut adalah sebagai berikut:

1. Kesulitan dalam menangkap suara penutur asli bahasa Inggris.

Terdapat lima penyebab utama kesulitan dalam menangkap suara penutur asli bahasa Inggris yaitu penyampaian yang cepat $(77,27 \%)$, tidak adanya kesempatan mengulang tuturan (72,73\%), ketidakjelasan pengucapan penutur $(68,18 \%)$, volume rendah $(63,64 \%)$, dan kosakata yang tidak dikenal dan sulit $(59,09 \%)$. Lima penyebab utama tersebut dapat dilihat pada Tabel 1.

Tabel 1 Penyebab Kesulitan dalam menangkap suara penutur asli bahasa Inggris

\begin{tabular}{|l|l|l|}
\hline No & \multicolumn{1}{|c|}{ Penyebab Kesulitan } & \multicolumn{1}{|c|}{ Persentase } \\
\hline 1 & Suara yang mengganggu di sekeliling & $50 \%$ \\
\hline 2 & Suara tumpang tindih & $40,91 \%$ \\
\hline 3 & Aksen asing & $45,45 \%$ \\
\hline 4 & Volume Rendah & $\mathbf{6 3 , 6 4 \%}$ \\
\hline 5 & Ketidakjelasan pengucapan penutur & $\mathbf{6 8 , 1 8 \%}$ \\
\hline
\end{tabular}




\begin{tabular}{|l|l|l|}
\hline 6 & Kosakata yang tidak dikenal dan sulit & $\mathbf{5 9 , 0 9 \%}$ \\
\hline 7 & Struktur yang sulit & $18,18 \%$ \\
\hline 8 & Penyampaian yang cepat & $\mathbf{7 7 , 2 7 \%}$ \\
\hline 9 & Tidak adanya kesempatan mengulang tuturan & $\mathbf{7 2 , 7 3 \%}$ \\
\hline
\end{tabular}

2. Kesulitan dalam memahami setiap kosa kata yang tidak dikenal (unfamiliar vocabulary).

Tabel 2 Penyebab Kesulitan dalam memahami setiap kosa kata yang tidak dikenal

\begin{tabular}{|l|l|l|}
\hline No & \multicolumn{1}{|c|}{ Penyebab Kesulitan } & Persentase \\
\hline 1 & Suara yang mengganggu di sekeliling & $40,91 \%$ \\
\hline 2 & Elision (penghilangan huruf hidup) & $27,27 \%$ \\
\hline 3 & Aksen asing & $\mathbf{5 0 \%}$ \\
\hline 4 & Ketidakjelasan pengucapan penutur & $\mathbf{7 7 , 2 7 \%}$ \\
\hline 5 & Kosakata yang tidak dikenal dan sulit & $\mathbf{6 3 , 6 4 \%}$ \\
\hline 6 & Struktur yang sulit & $27,27 \%$ \\
\hline 7 & Penyampaian yang cepat & $\mathbf{8 6 , 3 6 \%}$ \\
\hline 8 & Tidak adanya kesempatan mengulang tuturan & $\mathbf{7 2 , 7 3 \%}$ \\
\hline
\end{tabular}

Dari delapan penyebab kesulitan dalam memahami setiap kosa kata yang tidak dikenal (unfamiliar vocabulary) yang ditunjukkan pada Tabel 2, terdapat lima penyebab utama yaitu penyampaian yang cepat $(86,36 \%)$, ketidakjelasan pengucapan penutur $(77,27 \%)$, tidak adanya kesempatan mengulang tuturan $(72,73 \%)$, kosakata yang tidak dikenal dan sulit $(63,64 \%)$ dan aksen asing (50\%).

3. Kesulitan dalam memahami suara yang cepat dari penutur asli (aksen penutur).

Tabel 3 Penyebab Kesulitan dalam memahami suara yang cepat dari penutur asli

\begin{tabular}{|l|l|l|}
\hline No & \multicolumn{1}{|c|}{ Penyebab Kesulitan } & Persentase \\
\hline 1 & Suara yang mengganggu di sekeliling & $50 \%$ \\
\hline 2 & Suara tumpang tindih & $\mathbf{6 3 , 6 4 \%}$ \\
\hline 3 & Aksen asing & $\mathbf{5 4 , 5 5 \%}$ \\
\hline 4 & Volume Rendah & $\mathbf{5 9 , 0 9 \%}$ \\
\hline
\end{tabular}




\begin{tabular}{|l|l|l|}
\hline 5 & Ketidakjelasan pengucapan penutur & $\mathbf{7 7 , 2 7 \%}$ \\
\hline 6 & Kosakata yang tidak dikenal dan sulit & $45,45 \%$ \\
\hline 7 & Struktur yang sulit & $18,18 \%$ \\
\hline 8 & Penyampaian yang cepat & $\mathbf{7 7 , 2 7 \%}$ \\
\hline 9 & Tidak adanya kesempatan mengulang tuturan & $\mathbf{8 1 , 8 2 \%}$ \\
\hline
\end{tabular}

Kesulitan yang dialami oleh mahasiswa dalam memahami suara yang cepat dari penutur asli dapat disebabkan oleh sembilan faktor yang dapat dilihat pada Tabel 3. Lima faktor penyebab terbesar adalah tidak adanya kesempatan mengulang tuturan $(81,82 \%)$, penyampaian yang cepat $(77,27 \%)$, ketidakjelasan pengucapan penutur $(77,27 \%)$, volume rendah $(59,09 \%)$ dan aksen asing $(54,55 \%)$.

4. Kesulitan memahami teks yang disimak dalam waktu yang relatif singkat.

Menurut Tabel 4, lima penyebab utama kesulitan memahami teks yang disimak dalam waktu yang relatif singkat adalah waktu respon atau waktu menjawab yang relatif singkat menduduki peringkat pertama $(90,91 \%)$, ketidaktahuan terhadap topik yang dibicarakan menduduki peringkat kedua $(86,36 \%)$, yang ketiga adalah ketidaktahuan terhadap topik yang dibicarakan $(68,18 \%)$, dan panjangnya teks dan penyampaian yang cepat $(59,09 \%)$.

Tabel 4 Penyebab Kesulitan memahami teks yang disimak dalam waktu yang relatif singkat

\begin{tabular}{|l|l|l|}
\hline No & Penyebab Kesulitan & Persentase \\
\hline 1 & Jenis teks yang berisi penalaran abstrak & $\mathbf{6 3 , 6 4 \%}$ \\
\hline 2 & Suara yang mengganggu di sekeliling & $50 \%$ \\
\hline 3 & Ketidakjelasan pengucapan penutur & $54,55 \%$ \\
\hline 4 & Panjangnya teks & $\mathbf{5 9 , 0 9 \%}$ \\
\hline 5 & $\begin{array}{l}\text { Waktu respon atau waktu menjawab yang } \\
\text { singkat }\end{array}$ & $\mathbf{9 0 , 9 1 \%}$ \\
\hline 6 & Kosa kata yang tidak dikenal dan sulit & $54,55 \%$ \\
\hline 7 & Struktur yang sulit & $31,82 \%$ \\
\hline 8 & Ketidaktahuan terhadap topik yang dibicarakan & $\mathbf{6 8 , 1 8 \%}$ \\
\hline 9 & Penyampaian yang cepat & $\mathbf{5 9 , 0 9 \%}$ \\
\hline
\end{tabular}




\begin{tabular}{|l|l|l|}
\hline 10 & Tidak adanya kesempatan mengulang tuturan & $\mathbf{8 6 , 3 6 \%}$ \\
\hline
\end{tabular}

5. Kesulitan berkonsentrasi dalam waktu yang lama (lack of concentration).

Tabel 5 Penyebab Kesulitan berkonsentrasi dalam waktu yang lama

\begin{tabular}{|l|l|l|}
\hline No & \multicolumn{1}{|c|}{ Penyebab Kesulitan } & \multicolumn{1}{|c|}{ Persentase } \\
\hline 1 & Suara yang mengganggu di sekeliling & $45,45 \%$ \\
\hline 2 & Panjangnya teks & $\mathbf{7 7 , 2 7 \%}$ \\
\hline 3 & Penyampaian yang cepat & $\mathbf{5 9 , 0 9 \%}$ \\
\hline 4 & Kondisi fisik yang menurun & $\mathbf{7 7 , 2 7 \%}$ \\
\hline 5 & Kemampuan konsentrasi yang lemah & $\mathbf{5 4 , 5 5 \%}$ \\
\hline 6 & Daya ingat yang lemah & $\mathbf{5 9 , 0 9 \%}$ \\
\hline 7 & Suhu di sekitar ruangan & $18,18 \%$ \\
\hline
\end{tabular}

Berdasarkan Tabel 5, kesulitan berkonsentrasi dalam waktu yang lama ketika mengikuti tes dapat disebabkan oleh panjangnya teks dan kondisi fisik yang menurun $(77,27 \%)$ dipilih oleh para responden sebagai dua penyebab kesulitan mereka, dan dua penyebab kesulitan berikutnya adalah penyampaian yang cepat dan daya ingat yang lemah $(59,09 \%)$.

6. Kesulitan menginterpretasikan wacana.

Tabel 6 Penyebab Kesulitan menginterpretasikan wacana

\begin{tabular}{|l|l|l|}
\hline No & \multicolumn{1}{|c|}{ Penyebab Kesulitan } & \multicolumn{1}{|c|}{ Persentase } \\
\hline 1 & Instruksi yang rumit & $54,55 \%$ \\
\hline 2 & Jenis teks yang berisi penalaran abstrak & $\mathbf{7 7 , 2 7 \%}$ \\
\hline 3 & Suara yang mengganggu di sekeliling & $40,91 \%$ \\
\hline 4 & Kejelasan pengucapan & $59,09 \%$ \\
\hline 5 & Panjangnya teks & $\mathbf{6 8 , 1 8 \%}$ \\
\hline 6 & $\begin{array}{l}\text { Waktu respon atau waktu menjawab yang } \\
\text { singkat }\end{array}$ & $\mathbf{8 1 , 8 2 \%}$ \\
\hline 7 & Kosa kata yang tidak dikenal dan sulit & $54,55 \%$ \\
\hline 8 & Struktur yang sulit & $31,82 \%$ \\
\hline
\end{tabular}




\begin{tabular}{|l|l|l|}
\hline 9 & Ketidaktahuan terhadap topik yang dibicarakan & $63,64 \%$ \\
\hline 10 & Penyampaian yang cepat & $\mathbf{6 8 , 1 8 \%}$ \\
\hline 11 & Tidak adanya kesempatan mengulang tuturan & $\mathbf{8 1 , 8 2 \%}$ \\
\hline
\end{tabular}

Menurut Tabel 6, lima penyebab utama kesulitan dalam menginterpretasikan wacana adalah waktu respon atau waktu menjawab yang singkat dan tidak adanya mengulang tuturan $(81,82 \%)$, jenis teks yang berisi penalaran abstrak $(77,27 \%)$, panjangnya teks dan penyampaian yang cepat $(68,18 \%)$.

7. Kesulitan dalam menampung informasi yang relatif banyak dalam waktu yang singkat.

Terdapat lima penyebab utama kesulitan dalam menampung informasi yang bersifat demikian yaitu tidak adanya kesempatan mengulang tuturan $(86,36 \%)$, waktu respon atau waktu menjawab yang singkat dan penyampaian yang cepat $(81,82 \%)$, panjangnya teks $(72,73 \%)$, serta ketidakjelasan pengucapan penutur $(68,18 \%)$. Lima penyebab utama itu ditampilkan pada Tabel 7.

Tabel 7 Penyebab Kesulitan dalam menampung informasi yang relatif banyak dalam waktu yang singkat.

\begin{tabular}{|l|l|l|}
\hline No & \multicolumn{1}{|c|}{ Penyebab Kesulitan } & \multicolumn{1}{|c|}{ Persentase } \\
\hline 1 & Suara yang mengganggu di sekeliling & $45,45 \%$ \\
\hline 2 & Kejelasan pengucapan & $54,55 \%$ \\
\hline 3 & Panjangnya teks & $\mathbf{7 2 , 7 3 \%}$ \\
\hline 4 & $\begin{array}{l}\text { Waktu respon atau waktu menjawab yang } \\
\text { singkat }\end{array}$ & $\mathbf{8 1 , 8 2 \%}$ \\
\hline 5 & Kosa kata yang tidak dikenal dan sulit & $\mathbf{6 8 , 1 8 \%}$ \\
\hline 6 & Struktur yang sulit & $40,91 \%$ \\
\hline 7 & Ketidaktahuan terhadap topik yang dibicarakan & $50 \%$ \\
\hline 8 & Penyampaian yang cepat & $\mathbf{8 1 , 8 2 \%}$ \\
\hline 9 & Tidak adanya kesempatan mengulang tuturan & $\mathbf{8 6 , 3 6 \%}$ \\
\hline 10 & Daya ingat yang lemah & $59,09 \%$ \\
\hline
\end{tabular}


Dari data yang dianalisis, dihasilkan simpulan bahwa kesulitan mahasiswa dalam menyimak ketika mengikuti tes TOEIC pada bagian Listening Comprehension adalah pembelajar tidak dapat mengatur kecepatan ujaran dari penutur asli, pembelajar tidak bisa meminta kata-kata diulangi kembali atau tidak bisa meminta untuk diputar kembali rekaman tersebut dan pembelajar tidak mudah berkonsentrasi pada materi menyimak. Temuan studi ini sejalan dengan laporan penelitian dari Underwood (1989).

\section{Analisis data dari angket tentang strategi menyimak yang dilakukan pembelajar untuk memahami bagian Listening Comprehension pada tes TOEIC.}

Persentase hasil dari kuesioner tentang strategi menyimak yang dilakukan pembelajar untuk memahami bagian Listening Comprehension pada tes TOEIC ditampilkan pada Tabel 8 .

Tabel 8 Persentase hasil dari kuesioner tentang strategi menyimak

\begin{tabular}{|c|l|c|}
\hline No & \multicolumn{1}{|c|}{ Pernyataan } & persentase \\
\hline p1 & $\begin{array}{l}\text { Sebelum mendengarkan, saya mengklarifikasikan } \\
\text { tujuan dari tugas menyimak dan/ atau menyiapkan } \\
\text { beberapa strategi untuk memahaminya. }\end{array}$ & $70 \%$ \\
\hline p2 & $\begin{array}{l}\text { Sebelum mendengarkan, saya berkonsentrasi pada } \\
\text { kegiatan mendengarkan tanpa menghiraukan segala } \\
\text { sesuatu yang mengganggu konsentrasi saya. }\end{array}$ & $84 \%$ \\
\hline p3 & $\begin{array}{l}\text { Sebelum mendengarkan, pertama-tama saya melihat } \\
\text { secara cepat daftar pertanyaan yang ada di bawah } \\
\text { teks, kemudian saya memutuskan untuk } \\
\text { mendengarkan hal-hal khusus dalam teks yang } \\
\text { berhubungan dengan pertanyaan-pertanyaan } \\
\text { tersebut. }\end{array}$ & $81 \%$ \\
\hline p4 & $\begin{array}{l}\text { Selama mendengarkan, saya mencoba mengikuti } \\
\text { kecepatan yang ada. }\end{array}$ & $81 \%$ \\
\hline p5 & $\begin{array}{l}\text { Selama mendengarkan, saya mereka-reka dan } \\
\text { menarik kesimpulan terkait dengan apa yang sedang } \\
\text { saya dengarkan atau seberapa banyak yang telah } \\
\text { saya pahami. }\end{array}$ & $78 \%$ \\
\hline p6 & $\begin{array}{l}\text { Saya menyadari konsentrasi yang kurang dan } \\
\text { berusaha fokus kembali pada materi yang sedang } \\
\text { saya dengarkan. }\end{array}$ & $75 \%$ \\
\hline
\end{tabular}




\begin{tabular}{|c|c|c|}
\hline $\mathrm{p} 7$ & $\begin{array}{l}\text { Setelah mendengarkan, saya memeriksa kembali } \\
\text { pemahaman dari apa yang telah saya dengarkan } \\
\text { kemudian mencoba memperbaiki kesalahan - } \\
\text { kesalahan pada jawaban saya }\end{array}$ & $70 \%$ \\
\hline p8 & $\begin{array}{l}\text { Setelah mendengarkan, saya membuka kamus untuk } \\
\text { memeriksa pemahaman saya atas teks yang telah } \\
\text { saya simak. }\end{array}$ & $52 \%$ \\
\hline p9 & $\begin{array}{l}\text { Setelah mendengarkan, saya memikirkan } \\
\text { permasalahan- permasalahan atau kesulitan- } \\
\text { kesulitan seperti tingkat kecepatan yang terlalu } \\
\text { tinggi atau hubungan antar ide yang sulit dimengerti. }\end{array}$ & $71 \%$ \\
\hline $\mathrm{p} 10$ & $\begin{array}{l}\text { Setelah mendengarkan, saya menggunakan sebuah } \\
\text { daftar untuk mengevaluasi peningkatan kemampuan } \\
\text { mendengarkan saya }\end{array}$ & $37 \%$ \\
\hline $\mathrm{p} 11$ & $\begin{array}{l}\text { Sebelum mendengarkan, saya meninjau materinya } \\
\text { terlebih dahulu. }\end{array}$ & $58 \%$ \\
\hline $\mathrm{p} 12$ & $\begin{array}{l}\text { Saya menggunakan beberapa perangkat untuk } \\
\text { memahami materi, seperti kamus, buku tata bahasa, } \\
\text { atau ensiklopedia. }\end{array}$ & $51 \%$ \\
\hline $\mathrm{p} 13$ & $\begin{array}{l}\text { Saya mencoba untuk menterjemahkan kata-kata atau } \\
\text { kalimat berbahasa Inggris dalam bahasa Indonesia. }\end{array}$ & $77 \%$ \\
\hline p14 & $\begin{array}{l}\text { Saya menggunakan penanda - penanda bahasa yang } \\
\text { dipakai dalam teks untuk memahami dialog, seperti } \\
\text { misalnya awalan dan akhiran. }\end{array}$ & $63 \%$ \\
\hline $\mathrm{p} 15$ & $\begin{array}{l}\text { Sambil mendengarkan, saya mengulangi kata-kata } \\
\text { atau frase secara pelan atau dalam hati }\end{array}$ & $82 \%$ \\
\hline p16 & $\begin{array}{l}\text { Saya menggunakan cara pengucapan, intonasi dan } \\
\text { jeda untuk memahami kalimat- kalimat. }\end{array}$ & $73 \%$ \\
\hline p17 & $\begin{array}{l}\text { Saya memperhatikan hal-hal pokok atau inti pada } \\
\text { dialog. }\end{array}$ & $78 \%$ \\
\hline p18 & $\begin{array}{l}\text { Saya mencari gagasan pokok lebih dahulu, setelah } \\
\text { itu gagasan pendukung. }\end{array}$ & $76 \%$ \\
\hline p19 & $\begin{array}{l}\text { Saya mencoba membuat dugaan sementara } \\
\text { mengenai isi teks dengan dasar judulnya lalu } \\
\text { melakukan pembuktikan ketika menyimak. }\end{array}$ & $66 \%$ \\
\hline p20 & $\begin{array}{l}\text { Saya memperkirakan makna dari kata yang tidak } \\
\text { saya ketahui dengan cara mencari padanannya yang } \\
\text { lebih umum. }\end{array}$ & $82 \%$ \\
\hline
\end{tabular}




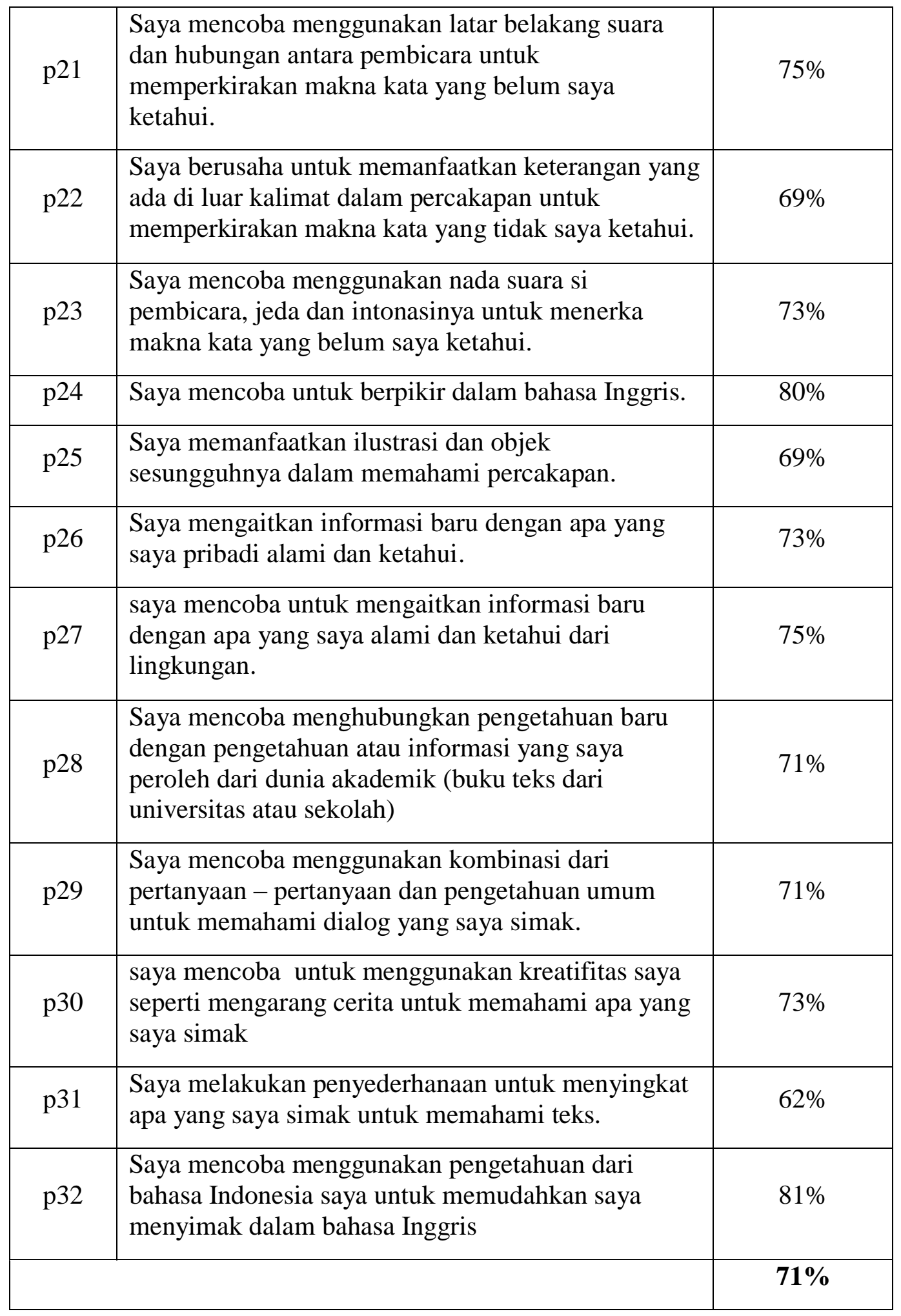

Pada Tabel 8 dapat dilihat bahwa $71 \%$ mahasiswa menggunakan strategi metakognitif dalam mengatasi kesulitan-kesulitan dalam menyimak ketika mengikuti tes TOEIC, di antaranya p1, p2, p4, p6, p7, p8, p10, p11, artinya mahasiswa memiliki 
kesadaran berfikir tentang apa yang diketahui dan yang tidak diketahui ketika menyimak. Dalam konteks pembelajaran menyimak, siswa mengetahui bagaimana untuk belajar menyimak, mengetahui kemampuan dan modalitas belajar menyimak yang dimiliki, dan mengetahui strategi belajar menyimak terbaik untuk belajar efektif.

Pembelajar yang menggunakan strategi metakognitif memiliki kelebihan, seperti dapat memahami materi dengan lebih cepat dan memadukan ilmu pengetahuan secara mendalam, dapat memposisikan dirinya sebagai pembelajar yang menerima secara penuh materi yang diajarkan dan dapat menyesuaikan diri dengan semua situasi, memiliki kepercayaan diri untuk menerima masukan dari teman, guru, atau keluarga saat diperlukan, dapat menyelidiki dan mengevaluasi cara untuk menjadi pembelajar yang sukses serta dapat mengatasi situasi yang bermasalah melalui latihan yang mereka kerjakan (Wenden, 1998 dalam Bingol, dkk., 2014).

\section{SIMPULAN DAN SARAN}

\section{Simpulan}

Penelitian ini menentukan kesulitan-kesulitan yang dihadapi mahasiswa ketika memahami bagian Listening Comprehension dalam tes TOEIC, dan mengidentifikasi strategi yang dilakukan mahasiswa dalam mengatasi kesulitan-kesulitan tersebut. Simpulan tersebut dipaparkan sebagai berikut:

1. Dari hasil angket yang diteliti, mahasiswa kadang-kadang mengalami kesulitan $(81,8 \%)$ dalam menyimak tes TOEIC.

2. Berdasarkan hasil angket terdapat dua bagian yang dirasa sulit oleh mahasiswa dalam mengerjakan tes TOEIC (Listening Comprehension) yaitu Conversations (50\%) dan Talks $(31,8 \%)$. Namun dari hasil wawancara ditemukan bagian yang dirasa paling sulit adalah bagian Talks. Hal ini dimungkinkan terjadi karena mahasiswa tidak mengetahui nama istilah yang digunakan dalam tes TOEIC.

3. Berdasarkan data angket, kesulitan mahasiswa dalam menyimak ketika mengikuti tes TOEIC pada bagian Listening Comprehension adalah pembelajar kesulitan menampung informasi yang banyak dalam waktu yang relatif singkat (64,09\%), menginterpretasikan wacana $(61,98 \%)$, memahami teks yang disimak dalam waktu 
yang relatif singkat $(61,82 \%)$, memahami suara cepat penutur asli $(58,59 \%)$, berkonsentrasi dalam waktu lama $(55,84 \%)$, memahami setiap kata $(55,68 \%)$ dan menangkap suara penutur asli bahasa Inggris (55,05\%). Kesulitan-kesulitan tersebut disebabkan tidak adanya kesempatan mengulang tuturan dan penyampaian yang cepat dari penutur asli, waktu respon atau waktu menjawab yang singkat, dan teks yang panjang.

\section{Saran}

Ada beberapa permasalahan yang belum terpecahkan dari hasil penelitian ini , untuk itu peneliti memberikan saran-saran, khususnya untuk dosen pengampu mata kuliah Listening sebagai berikut:

1. memberikan materi-materi yang diujikan dalam tes TOEIC, seperti materi pidato, iklan/media, pameran, museum, dan sebagainya.

2. memotivasi pembelajar untuk melakukan belajar mandiri dengan memberikan tugas seperti: mendengarkan podcasts di internet, mendengarkan berita dari CNN atau $\mathrm{BBC}$ di radio atau di internet, menonton film dan TV berbahasa Inggris, menonton video yang menarik dari Youtube, dan mendengarkan lagu berbahasa Inggris. Hasil dari tugas mandiri tersebut dilaporkan dalam bentuk presentasi individu dan atau melengkapi lembar kerja mahasiswa yang sudah disediakan oleh dosen. Untuk selanjutnya didiskusikan bersama di dalam kelas tentang materi yang dibahasnya.

3. memberikan banyak latihan menyimak tentang materi yang diujikan dalam tes TOEIC yang mencakup analisis gambar, analisis pilihan jawaban, analisis jenis-jenis pertanyaan (WH questions, Yes/No questions, Tag questions, and Reply questions), dan analisis language functions agar target pada bagian Listening Comprehension tercapai.

Kajian penelitian ini terkait dengan kesulitan menyimak dan strategi memahaminya pada bagian Listening Comprehension tes TOEIC. Selain bagian Listening Comprehension, tes TOEIC juga menguji tiga keterampilan berbahasa lainnya, yaitu Reading Comprehension, Speaking, dan Writing. Untuk penelitian selanjutnya disarankan kajian yang terkait dengan tiga keterampilan tersebut. Selain 
pada tes TOEIC, kajian penelitian juga dapat dilakukan pada tes TOEFL (Test of English as a Foreign Language).

\section{DAFTAR PUSTAKA}

Abdalhamid, F. (2012). Listening Comprehension Strategies of Arabic-Speaking ESL Learners. Master's Dissertation, Department of English, Colorado State University, Fort Collins, Colorado.

Aneiro, S. (1989). The Influence of Receiver Apprehension in Foreign Language Learners on Listening Comprehension among Puerto Rican College Students. (Unpublished doctoral dissertation). New York University: New York.

Anh, K. N. N. (2015). Difficulties and Strategies in Listening Comprehension (Trinh Vinh Hien 03AV4). [Online] dari https://lhu.edu.vn/139/662/DIFFICULTIESAND-\%20STRATEGIES-\%20IN\%20-LISTENING\%20COMPREHENSIONTRINH-VINH-HIEN-03AV4 [10 Oktober 2018]

Bingol, M. A., Celik, B., Yidliz, N., \& Mart, C. T. (2014). Listening Comprehension Difficulties Encountered by Students in Second language Learning Class. Journal of Educational and Instructional Studies in the World, 4(4), 1-6.

Darmawan. (2001). Peningkatan Keterampilan Menyimak dengan Menggunakan Media Audio pada Siswa Kelas 2 Kaliwungu Kudus. Skripsi. UNNES.

Gilakjani, Abbas Pourhosein; Sabouri, Narjes Banou. (2016). Learners' Listening Comprehension Difficulties in English Language Learning: A Literature Review. English Language Teaching, v9 n6 p123-133. http://dx.doi.org/10.5539/elt.v9n6p123

Goh, C. (1999). Teaching Listening in the Language Classroom. Singapore: SEAMEO Regional Language Centre.

Lougheed, Lin. (n.d). Barron's TOEIC. 5th Edition. Indonesia: Binarupa Aksara.

Moleong, Lexy J. (2015). Metodologi Penelitian Kualitatif. Edisi Revisi. Bandung: Rosdakarya.

Sabarti, A. dkk (1992). Pembinaan Kemampuan Menulis Bahasa Indonesia. Jakarta: Erlangga.

Tarigan, H.G. (1985). Menyimak Sebagai Suatu Keterampilan Berbahasa. Bandung : Angkasa. . (1994). Menyimak Sebagai Suatu Keterampilan Berbahasa. Bandung : 
Angkasa.

Tarigan, Djago. (1991). Pendidikan Bahasa Indonesia 1. Jakarta: DEPDIKBUD

Tarigan, Henry Guntur. (2008). Berbicara Sebagai Suatu Keterampilan berbahasa. Bandung: Angkasa.

Underwood, M. (1989). Teaching listening. London: Longman.

Vandergrift, L. (2003). Orchestrating Strategy Use: Towards a Model of the Skilled L2 Listener. Language learning, 53, 461-491. http://dx.doi.org/10.1111/14679922.00232

. (n.d). TOEIC-International Test Center. [Online] dari http://itcindonesia.com [10 Oktober 2018] 